\title{
Metropolitan smart-growth centers: An assessment of incentive policies in four regions
}

\author{
Richard D. Margerum ${ }^{a}$ \\ University of Oregon
}

\author{
Robert Parker \\ University of Oregon
}

\author{
Susan Brody \\ Portland State University
}

\author{
Gail McEwen \\ Portland State University
}

\begin{abstract}
Across the United States, metropolitan areas face challenges related to transportation and land use. An emerging policy in many regions is to promote development around higher-density, mixed-use (smart-growth) centers that create locally accessible nodes; many of these nodes are also linked to transit stops. Some metropolitan planning organizations (MPOs) have developed regional plans and incentive programs to encourage local governments to develop these centers. Incentives include grants as well as funding criteria in transportation improvement programs (TIP) that favor projects supporting centers. This paper assesses these policies as they have been applied in: (1) Puget Sound, Washington; (2) Portland, Oregon; (3) Denver, Colorado; and (4) San Diego, California. For the four regions we reviewed documents, conducted 40 interviews with key individuals, administered an online survey of 450 experts (response rate $=44$ percent), and held a two-day forum involving 40 participants. We found that incentive policies by themselves were having a limited impact because they are new and offer small amounts of funding relative to local government needs and market forces. However, when incentives are combined with plans, policies, and transit investment, they provide a significant foundation for promoting growth around centers. There are a number of ways these policies can be improved, and many policies are transferable to other metropolitan regions.
\end{abstract}

\section{Introduction}

Across the United States, metropolitan areas face increasing challenges related to transportation and land use, including congestion, infrastructure costs, air quality, loss of open space, and greenhouse gas emissions. These issues are closely interrelated with the form and patterns of land use, but as Cervero (2003) notes, the separation of land-use and transportation decisions makes coordination efforts difficult. In particular, land-use decisions are fragmented across many local governments, while transportation and transit planning is carried out at the regional and state level. In some metropolitan regions, metropolitan planning organizations (MPOs) are working on a regional scale to develop policies that better coordinate land use and transportation decisions (Reconnecting America 2011; Cervero 2003).

One of the common policy concepts among MPOs is to promote more intensive development around centers, which are referred to as "smart-growth centers," "mixed-use centers," or "metropolitan centers." The definition and composition of these centers vary depending on their intended function. Some are defined in terms of areas of concentrated employment. Some centers are defined by higher-density housing and a mix of uses. Finally, many of these center locations are selected because they are served (or have the potential to be served) by bus or rail transit, which is referred to as transit-oriented development (Bernick and Cervero 1997; Dunphy 2004). Some of the objectives of encouraging development in these locations are to (1) increase the supply of more affordable multi-family housing, (2) reduce vehicle miles traveled by promoting development near services and employment, and (3) intensify development in locations served by bus or rail transit (Bernick and Cervero 1997; Dunphy 2004; Cervero et al. 2002; Dittmar and Ohland 2004; Calthorpe 1993).

Centers and transit-oriented development (TOD) have received considerable attention in the literature. Publications examine a number of issues related to centers, including market dynamics, elements of effective centers, and evaluating effects on travel patterns and behavior (Dunphy 2004; Nelson and Niles 1999; Handy 2005). However, few studies have evaluated the plans and policies of MPOs to promote the development of centers across metropolitan regions. Several authors have identified strategies for coordinating transportation and land use, but this research has focused on topics such as travel demand tools, forecasting, and legislative options (Rodíguez and Godschalk 2003; Miller et al. 2004; Hendricks and

\footnotetext{
ardm@uoregon.edu
} 
Seggerman 2005). As Rodíguez and Godschalk (2003) note, there is a need to identify institutional mechanisms that allow state and regional transportation planners "to reach out to local land-use planners to increase collaboration among parties and improve planning outcomes."

Our goal in this study was to assess policies in metropoli$\tan$ regions designed to promote development around centers. Specifically, we were interested in how MPOs have used regional plans and financial incentives to encourage local governments to develop centers. Based on a review of MPO activities and programs, we identified two commonly used incentives. First, some MPOs allocate grants to local governments to help them with planning, infrastructure, land purchases, and public facilities at designated centers.

Second, some MPOs include criteria in their transportation incentive program (TIP) process that favor projects serving or supporting centers. As part of federal transportation planning processes, MPOs in the United States are responsible for allocating federal funding for maintenance and improvements through a TIP. This allocation typically happens on a biannual basis, and MPOs have some flexibility with the criteria they use to allocate the funding. These criteria are determined by the MPO as part of its regional transportation plan, which must be approved by the Federal Highway Administration (FHWA) and the Federal Transit Administration (FTA).

\section{$2 \quad$ Methods}

To assess regional center policies, we reviewed the literature, research reports, state agency documents, and websites to identify potential cases for investigation. In selecting our cases, we used four criteria derived from policy and research discussions about regional-scale tools to promote smart-growth centers (Barbour and Teitz 2009; Zimbabwe and Anderson 2011; CH2MHill 2005). First, the region had to be addressing land use and transportation on a regional scale, as opposed to cases involving a specific city. Second, the region had to have a regional centers plan in place that defined and designated centers. Third, we wanted to select regions that were using financial incentives to promote these centers. Finally, we wanted to select regions with and without regional land-use authority to assess the influence of both incentives and regulations.

A report by $\mathrm{CH} 2 \mathrm{MHill}$ for the Atlanta Regional Commission identified five different MPOs that are using TIP criteria to incentivize local investment in centers $(\mathrm{CH} 2 \mathrm{MHill}$ 2005). We contacted all five MPOs and four agreed to participate in our study: (1) Puget Sound Regional Commission in Washington, (2) Portland Metropolitan Service District in Oregon, (3) Denver Regional Council of Governments in Colorado, and (4) San Diego Association of Governments in California. For each case study, the research team reviewed docu- ments, research reports, and published research. The team then conducted interviews with approximately 10 key individuals in each region that focused on how their incentive programs were structured and how they were working. The team also conducted two group interviews with the Regional Project Evaluation Committee (RPEC) in Puget Sound and the Transportation Policy Advisory Committee (TPAC) in the Portland metro region.

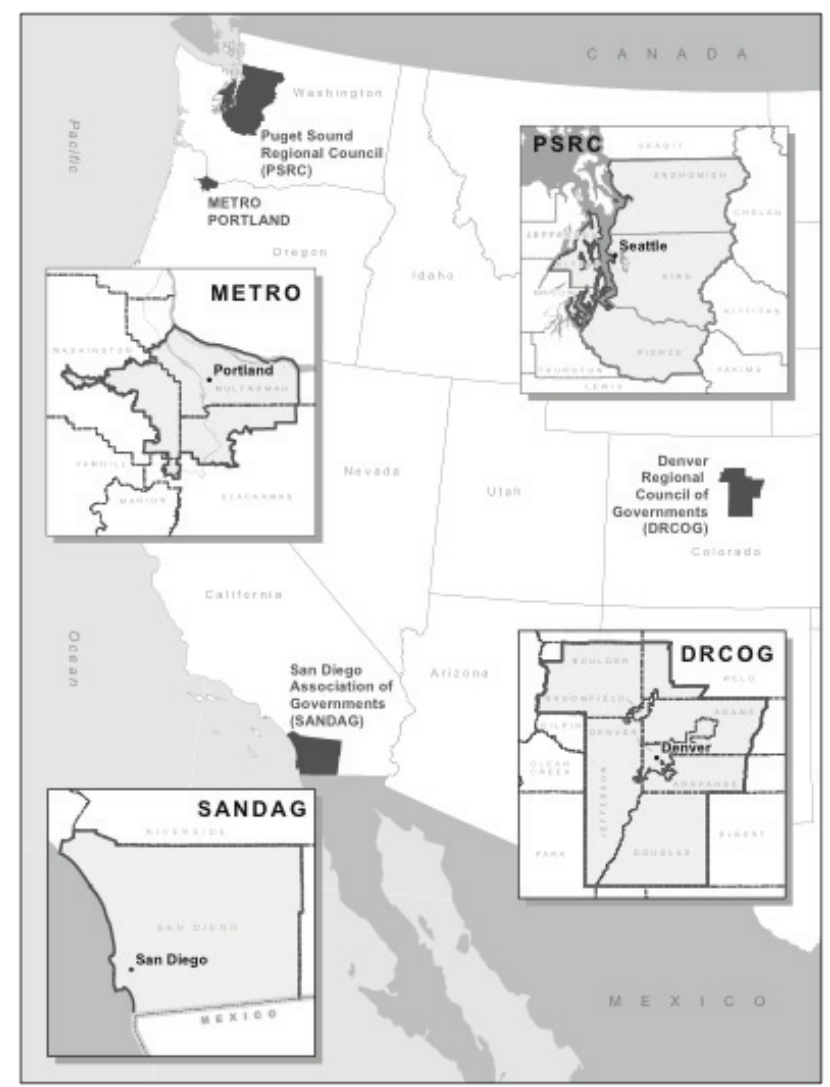

Figure 1: Case studies.

Source: InforGraphics Lab, Geography Department, University of Oregon

For each case study we conducted a survey of committees involved in regional transportation and land-use decision making, which included representatives of local government staff, elected officials, state agency staff, regional agency staff, and nongovernmental members. Individuals were contacted by email and asked to complete the survey online. After the initial e-mail message, two follow-up reminders were also sent. The survey was sent to a total of 450 individuals in the four regions, and a total of 199 responded (response rate $=44$ percent). A more detailed breakdown of the responses is provided in Table 1. The survey asked respondents to evaluate several issues in their region, but in this paper we focus on specific policies and programs related to supporting centers. 
Table 1: Survey responses and respondent characteristics.

\begin{tabular}{|l|r|r|r|r|}
\hline & Metro & PSRC & SANDAG & DRCOG \\
\hline Survey sample & $\mathbf{1 6 3}$ & $\mathbf{1 0 1}$ & $\mathbf{6 9}$ & $\mathbf{1 1 7}$ \\
\hline Survey responses & $\mathbf{4 4}$ & $\mathbf{6 1}$ & $\mathbf{3 5}$ & $\mathbf{5 9}$ \\
\hline Survey response rate & $\mathbf{2 7 \%}$ & $\mathbf{6 0} \%$ & $\mathbf{5 1 \%}$ & $\mathbf{5 0 \%}$ \\
\hline Organizational affiliation & & & & \\
\hline Federal government & $0 \%$ & $0 \%$ & $0 \%$ & $2 \%$ \\
\hline State government & $9 \%$ & $11 \%$ & $3 \%$ & $9 \%$ \\
\hline Local government & $41 \%$ & $54 \%$ & $77 \%$ & $71 \%$ \\
\hline Port & $2 \%$ & $7 \%$ & $0 \%$ & $0 \%$ \\
\hline Transit district & $5 \%$ & $10 \%$ & $3 \%$ & $4 \%$ \\
\hline Private sector & $11 \%$ & $7 \%$ & $0 \%$ & $3 \%$ \\
\hline MPO & $9 \%$ & $2 \%$ & $3 \%$ & $3 \%$ \\
\hline Interest group/community & $21 \%$ & $5 \%$ & $0 \%$ & $3 \%$ \\
\hline Other & $2 \%$ & $5 \%$ & $14 \%$ & $5 \%$ \\
\hline
\end{tabular}

The draft findings from this study were presented at a 1.5day research forum involving more than 40 people representing the case study MPOs, state agencies, the FHWA, the Environmental Protection Agency (EPA), and other researchers. In addition to presenting the findings, the attendees participated in breakout sessions that explored the issues of governance, funding, coordination mechanisms, and policy implications.

There are several limitations in our methods. We utilized a range of sources to assess the effectiveness of regional efforts, but our analysis relies heavily on the opinions of our interviewees and survey respondents. These respondents have a greater interest in these policies than a random sample of individuals. We relied on these experts because many people are unaware of the regional policies and programs, and there is little quantitative data to assess these programs in their early stages. Also, our case study interviews and surveys focused on similar types of committees and staff in each region, but variation of committee composition produced variation in the respondents by region (see Table 1). However, we did not identify substantial differences between respondents based on respondent categories, but the sample size in many categories was too small for statistical analysis. Finally, because the opinions of respondents are based on their own expectations and knowledge, we are cautious in directly comparing survey results across cases.

\subsection{Overview of case-study areas}

As shown in Table 2, all four regions include midsized cities with high rates of growth and metropolitan ranks ranging from 15 to 23 (US Census 2010). The table highlights variations in the MPO area, MPO population, governance arrangements, and land-use power.
Table 2: Overview of MPO case studies.

\begin{tabular}{|c|c|c|c|c|}
\hline Characteristics & Metro & PSRC & SANDAG & DRCOG \\
\hline MPO population ${ }^{1}$ & $1,400,000$ & $3,600,000$ & $3,200,000$ & $2,900,000$ \\
\hline MSA 2010 population rank ${ }^{2}$ & 23 & 15 & 17 & 21 \\
\hline MPO area (square miles) & 463 & 6,290 & 4,526 & 5,288 \\
\hline MSA 2009 population ${ }^{3}$ & $2,240,000$ & $3,400,000$ & $3,050,000$ & $2,550,000$ \\
\hline $\begin{array}{l}\text { MSA } 2000 \text { area (square } \\
\text { miles) }\end{array}$ & 474 & 954 & 782 & 499 \\
\hline $\begin{array}{l}1990-2000 \text { population } \\
\text { change }^{5}\end{array}$ & $26.5 \%$ & $18.9 \%$ & $12.6 \%$ & $30.7 \%$ \\
\hline Number of cities and counties & $\begin{array}{c}25 \text { cities } \\
3 \text { counties }\end{array}$ & $\begin{array}{l}82 \text { cities } \\
4 \text { counties }\end{array}$ & $\begin{array}{l}18 \text { cities } \\
1 \text { county }\end{array}$ & $\begin{array}{c}47 \text { cities } \\
9 \text { counties }\end{array}$ \\
\hline Size of executive committee & $\begin{array}{l}\text { Elected council: } \\
7 \text { members }\end{array}$ & $\begin{array}{c}\text { Board: } \\
32 \text { members }\end{array}$ & $\begin{array}{c}\text { Board: } \\
24 \text { mem- } \\
\text { bers }\end{array}$ & $\begin{array}{l}\text { Board: } \\
57 \text { members }\end{array}$ \\
\hline Regional land-use authority & Yes & Yes & No & No \\
\hline $\begin{array}{l}\text { Regional transit planning } \\
\text { authority }\end{array}$ & Yes & Yes & Yes & Yes \\
\hline $\begin{array}{l}\text { Regional transit planning } \\
\text { powers }\end{array}$ & No-TriMet & $\begin{array}{l}\text { No_-six transit } \\
\text { agencies }\end{array}$ & Yes & No-rTD \\
\hline Other related powers & $\begin{array}{l}\text { Oregon Transpor- } \\
\text { tation Planning } \\
\text { Rule mandates } \\
\text { land-use and } \\
\text { transportation } \\
\text { consistency }\end{array}$ & $\begin{array}{l}\text { Under state law, } \\
\text { responsible for } \\
\text { ensuring local } \\
\text { transportation } \\
\text { plans consistent } \\
\text { with regional } \\
\text { plans }\end{array}$ & $\begin{array}{l}\text { Under } \\
\text { state law, } \\
\text { allocates } \\
\text { local share } \\
\text { of regional } \\
\text { affordable } \\
\text { housing }\end{array}$ & \\
\hline
\end{tabular}

${ }^{1}$ Current MPO estimates.

${ }^{2}$ US Census Bureau, 2010.

${ }^{3}$ US Census Bureau. 2009.

${ }^{4}$ US Census Bureau. 2000. MSA area definitions: Portland-Beaverton, Oregon-Vancouver, Washington; Seattle-Tacoma-Bellevue, Washington, San Diego-Carlsbad-San Marcos, California, Denver-Aurora-Broomfield, Colorado.

${ }^{5}$ U.S. Census Bureau, Census 2000 and 1990. Internet release date: December 30, 2003.

\section{Portland Metro (Metro)}

Portland Metro encompasses three counties and 25 cities, including Portland, Beaverton, Tualatin, Oregon City, Milwaukie, Gresham, and Fairview. The Metropolitan Service District (Metro) covers 463 square miles, but its jurisdiction is considerably smaller than the greater metropolitan area, which extends to Vancouver, Washington (Metro 2010). The region is constrained by the Columbia River to the north and the Cascade Mountains to the east.

Metro formed through a merger of several regional organizations. Its formation was approved by the Oregon legislature in 1977 and approved by voters in 1978. In 1979 it started operations, adopted its first urban growth boundary, and was designated as the region's MPO. Local comprehensive plans in the region must be consistent with statewide planning goals, and Metro ensures consistency with its regional plans.

Adopted in 1995, the 2040 Growth Concept is Metro's growth-management policy that defines development in the 
metropolitan region. The 2040 Growth Concept directs most development to existing urban centers and along existing major transportation corridors and promotes a balanced transportation system with a variety of transportation options.

The Regional Transportation Plan (RTP) is the transportation system plan for the Portland metropolitan region. The RTP serves as the federal metropolitan transportation plan as well as the transportation system plan (TSP) required under the state's transportation planning rule. The first RTP was approved in 1982. The last update to the RTP, the $2035 \mathrm{RTP}$, was adopted in June 2010.

The Regional Framework Plan (RFP), adopted in 1996, unites under one document the 2040 Growth Concept, the Regional Urban Growth Goals and Objectives (RUGGOs), the Metropolitan Greenspaces Master Plan, and the RTP. The RFP contains regional policies on key regional growth issues, including accommodation of projected growth and the coordination of transportation and land-use planning (Metro 2007; Ingram 2009).

\section{Puget Sound Regional Council (PSRC)}

The Puget Sound Regional Council (PSRC) covers nearly 6,300 square miles and encompasses four counties (King, Snohomish, Pierce, and Kitsap) and 82 cities, including Seattle, Bellevue, Bremerton, Everett, and Tacoma. The region contains nearly 3.5 million residents with approximately 16 percent living in Seattle. Puget Sound has many channels and waterways that make transportation systems challenging. Furthermore, populated areas tend to concentrate near the sound, which creates land-use challenges due to the sensitivity of natural areas.

The first regional planning organization was established in 1959 and designated as a federal MPO in 1973. The PSRC was formed in 1992. Under Washington state law, the PSRC is also the designated regional transportation organization (RTPO).

The PSRC prepares the RTP, which satisfies both federal and state transportation requirements. Every one to two years, the PSRC is required to complete a federally approved Unified Planning Work Plan (UPWP). The PSRC also prepares the regional TIP, which was last updated in January 2009.

Under the Washington Growth Management Act, the PSRC prepared a long-range, integrated strategy called Vision 2040, which addresses regional environment, growth management, economic development, and transportation. Vision 2040 was adopted in 2008 as a comprehensive update to previous plans and allocates expected population and employment growth throughout the region. A key component of Vision 2040 is the designation of regional growth centers and manufacturing and industrial centers. The PSRC is responsible for ensuring that the transportation-related provisions in local comprehensive plans are consistent with the regional plan. Transportation 2040, an update to the regional transportation plan, was adopted in May 2010. It serves as the functional transportation plan for Vision 2040, with the goal of achieving a regional transportation system consistent with the regional vision (PSRC 2010; PSRC 2009).

\section{San Diego Association of Governments (SANDAG)}

The San Diego Association of Governments (SANDAG)'s boundaries coincide with San Diego County and encompass 18 cities, including San Diego, Carlsbad, Chula Vista, and Oceanside. The SANDAG region covers more than 4,000 square miles, and the total estimated population in 2009 was close to 3.2 million, with over half of this population living in San Diego (SANDAG 2012). SANDAG is bounded by Mexico to the south, the Pacific Ocean to the west, mountains to the east, and a military base to the north.

Although SANDAG was not created until 1980, it was preceded by a comprehensive planning organization (CPO) created in 1966. The CPO was designated as the MPO in 1970. In 1971 it was designated the state regional transportation planning agency, and one year later it was reestablished as a separate joint powers authority, independent of county government (SANDAG 2010).

As a result of several proposals and reviews, the California Senate passed legislation in 2002 that strengthened SANDAG's authority in the region. The agency took over the regional transit planning and capital project development functions of the region's Metropolitan Transit System and the North County Transit District.

As the federal MPO, SANDAG is responsible for preparing a RTP and regional TIP. Its most recent transportation plan, which was approved in 2007, is titled San Diego 2030 Regional Transportation Plan: Pathways for the Future. Under state law, SANDAG is also responsible for coordinating the regional housing needs assessment in which it allocates regional housing needs by jurisdiction according to income categories (SANDAG 2011).

In 2004, SANDAG completed a regional comprehensive plan (RCP) designed to guide how the region should grow in terms of housing, transportation, environment, energy, and water. The RCP establishes a planning framework for integrating local land use with regional transportation decisions. The RCP does not supersede local government land-use authority, but examines cumulative development trends and creates incentives for smart-growth planning (SANDAG 2004).

\section{Denver Regional Council of Governments (DRCOG)}

Situated along the Front Range in Colorado, the Denver Regional Council of Government (DRCOG)'s planning area includes nine counties and 48 cities, including Denver, Boulder, Aurora, and Lakewood. The regional population is over 
2.7 million people, with more than 600,000 living in Denver (DRCOG 2009).

DRCOG was formed in 1968, but was preceded by an inter-county regional planning commission formed in 1955 . Under state law, it is authorized to make and adopt regional plans, but it does not have land-use implementation authority. With DRCOG's support, the regional transportation district (RTD) was formed in 1969 to manage the region's transit system. In 1971, DRCOG signed agreements with the RTD and state to manage transportation planning throughout the region.

As a federal MPO, DRCOG is responsible for preparing a RTP and regional TIP. In 2007, the DRCOG board adopted the multimodal 2035 Metro Vision Regional Transportation Plan, which was updated in 2011 to incorporate sustainability principles (DRCOG 2010).

DRCOG also prepared a regional comprehensive, longrange strategy called Metro Vision. Metro Vision is an umbrella plan that addresses growth and development, transportation, and the environment. Metro Vision provides the high-level policy context for more detailed plans, including the RTPs and local government plans, but local compliance with the plan is voluntary (DRCOG 2011). Regional planning is augmented by a voluntary agreement among Denver metro-area cities and counties called The Mile High Compact. Forty-six of the region's communities (covering 90 percent of the population) have signed the compact and pledged to adhere to the principles of Metro Vision (DRCOG 2000).

\subsection{Regional center policies}

In all four regions, regional center policies start with a regional land-use plan that identifies current and potential growth centers and classifies them into categories based on type and/or scale. As noted previously, in Puget Sound and Portland these plans are linked to regional land-use authority, while in Denver and San Diego they are not.

As noted, all four of our case-study regions have incorporated criteria into their TIP process that reward projects that support centers. These funds are often allocated through a complex array of funding categories and processes. Table 3 provides a simplified summary of these criteria. Finally, three of the MPOs have created grant programs to support the development of centers. The MPOs use a range of sources for these funds, but they are intended to assist local governments in preparing plans, providing infrastructure, or improving walking and biking facilities to enhance access to centers. The following sections summarize the plans and policies related to centers in each region.

\section{Portland Metro (Metro)}

Metro's 2040 Growth Concept identifies key growth centers and encourages high-density development in priority land-use areas such as town centers, regional centers, and corridors. The Urban Centers policy in the Growth Concept identifies guidelines for 37 high-density, mixed-use, pedestrian- and transitoriented activity nodes that are defined as either regional centers or town centers.

In 2009, Metro council initiated a competitive grant process for planning and development within the urban growth boundary. The grants are funded by a construction excise tax, and in June 2009 the council approved \$3.7 million for its first 17 projects (Metro 2010; PSRC 2010).

The Metro TIP includes projects and programs administered by Metro, Oregon Department of Transportation, and TriMet (Metro 2010). To facilitate the integration of transportation and land-use planning, the primary policy objective of the Metro TIP and the allocation of funding is to "leverage economic development in priority 2040 land-use areas through investment to support centers, industrial areas, and UGB [urban growth boundary] expansion areas with completed concept plans" (Metro 2008).

PSRC

Puget Sound Vision 2040 designates regional growth centers, manufacturing/industrial centers, and corridor projects that serve centers. The PSRC is responsible for developing multicounty planning policies for the four most densely populated counties (King, Kitsap, Pierce, and Snohomish). These policies provide a common framework for local planning in six topic areas: environment, housing, transportation, development patterns, economic development, and public services (PSRC 2008).

The TIP process differentiates between regional (PSRC) and county selection processes for projects. Although the counties are asked to use the same selection criteria as the PSRC does for regional projects, counties generally select more locally focused projects. For both county and regional transportation funds, the approved policy of the region is to set aside at least 10 percent of the combined estimated Surface Transportation Program (STP) and Congestion Mitigation and Air Quality (CMAQ) funds available for programming for nonmotorized projects in the four counties. All TIP projects are selected by the Regional Project Evaluation Committee (RPEC) through a process that uses a 100-point system. As noted in Table 3, the point criteria vary slightly depending on whether the funds come from the STP, CMAQ, or the FTA (PSRC 2009). 
Table 3: Metropolitan center policies.

\begin{tabular}{|c|c|c|c|c|}
\hline & Metro & PSRC & SANDAG & DRCOG \\
\hline Term used & Centers & Centers & $\begin{array}{l}\text { Smart-growth opportunity } \\
\text { areas }\end{array}$ & Urban centers \\
\hline Number of centers & 37 & $\begin{array}{l}35 \text { ( } 27 \text { regional; } 8 \text { manufac- } \\
\text { turing/industrial) }\end{array}$ & $\begin{array}{l}196 \text { ( } 85 \text { existing or planned } \\
111 \text { potential) }\end{array}$ & 85 \\
\hline Definition of centers & $\begin{array}{l}\text { "The focus for redevelop- } \\
\text { ment, multimodal transpor- } \\
\text { tation and concentrations of } \\
\text { households and employment } \\
\text { patterns." }\end{array}$ & $\begin{array}{l}\text { "Locations characterized by } \\
\text { compact, pedestrian-orient- } \\
\text { ed development, with a mix } \\
\text { of different office, commer- } \\
\text { cial, civic, entertainment, } \\
\text { and residential uses." } 7\end{array}$ & $\begin{array}{l}\text { Places that accommodate, or } \\
\text { have the potential to accom- } \\
\text { modate, higher residential } \\
\text { and/or employment densities. } \\
\text { They are pedestrian-friendly } \\
\text { activity centers that are } \\
\text { connected to other activity } \\
\text { centers by transit or could be } \\
\text { in the future. }{ }^{8}\end{array}$ & $\begin{array}{l}\text { "Active, pedestrian-friendly } \\
\text { places, with employment, } \\
\text { housing, and services in } \\
\text { close proximity to each } \\
\text { other... [They] will be } \\
\text { served by transit and [with] } \\
\text { riders and pedestrian-ori- } \\
\text { ented environments." }\end{array}$ \\
\hline Types of centers & $\begin{array}{l}\text { - Town Centers } \\
\text { - Regional Centers }\end{array}$ & $\begin{array}{l}\text { - Regional growth centers } \\
\text { - Manufacturing/industrial } \\
\text { centers }\end{array}$ & $\begin{array}{l}\text { - Metropolitan center } \\
\text { - Urban center } \\
\text { - Town center } \\
\text { - Community center } \\
\text { - Transit corridor } \\
\text { - Special-use center } \\
\text { - Rural community }\end{array}$ & $\begin{array}{l}\text { - Mixed-use centers } \\
\text { - Activity centers } \\
\text { - Regional corridors }\end{array}$ \\
\hline $\begin{array}{l}\text { Summary of center-related } \\
\text { TIP criteria }\end{array}$ & $\begin{array}{l}-25 \% \text { of metropolitan TIP } \\
\text { criteria for projects that } \\
\text { produce congestion relief and } \\
\text { promote use of alternative } \\
\text { modes } \\
\text { - } 40 \% \text { of metropolitan TIP } \\
\text { points based on project } \\
\text { support of regional land-use } \\
\text { goals }\end{array}$ & $\begin{array}{l}-70 \% \text { of surface transporta- } \\
\text { tion fund and congestion } \\
\text { management and air quality } \\
\text { criteria based on benefits to } \\
\text { centers } \\
\text { - } 50 \% \text { of congestion mitiga- } \\
\text { tion and air-quality criteria } \\
\text { based on benefits to centers } \\
\cdot 70 \% \text { of Federal Transit } \\
\text { Administration fund criteria } \\
\text { based on projects that serve } \\
\text { designated centers }{ }^{11}\end{array}$ & $\begin{array}{l}-5 \% \text { of highway corridor } \\
\text { criteria for projects serving } \\
\text { centers and } 15 \% \text { relate to liv- } \\
\text { ability and accessibility goals } \\
\cdot 20 \% \text { of high-occupancy } \\
\text { vehicle criteria for projects } \\
\text { that serve regional and/or } \\
\text { transit corridors } \\
-15 \% \text { of Federal Transit } \\
\text { Administration criteria for } \\
\text { projects that serve regional } \\
\text { centers }^{12}\end{array}$ & $\begin{array}{l}\text { - } 6 \% \text { of regional TIP } \\
\text { criteria for projects serving } \\
\text { urban centers } \\
\text { - } 4 \% \text { of regional TIP crite- } \\
\text { ria for projects near centers } \\
\text { for which local government } \\
\text { has adopted policies to sup- } \\
\text { port center development } \\
\text { - } 3 \% \text { of regional TIP } \\
\text { criteria for projects lo- } \\
\text { cated within urban growth } \\
\text { boundary/area }{ }^{13}\end{array}$ \\
\hline $\begin{array}{l}\text { MPO center grant } \\
\text { program }\end{array}$ & $\begin{array}{l}\text { Construction excise tax: } \$ 7 \\
\text { million to } \$ 10 \text { million over } 4 \\
\text { years }[\approx \$ 1.8 \text { million to } \$ 2.5 \\
\text { million per year]. Uses: Rede- } \\
\text { velopment projects, land } \\
\text { acquisition, planning }{ }^{14}\end{array}$ & No PSRC grants & $\begin{array}{l}\text { TransNet Sales Tax: } \$ 280 \\
\text { million over } 40 \text { years }[\approx \$ 7 \\
\text { million per year]. Uses: Plan- } \\
\text { ning studies, land acquisition } \\
\text { or infrastructure to support }_{\text {centers }}{ }^{15}\end{array}$ & $\begin{array}{l}\text { TIP: } \$ 3.5 \text { million over } 4 \\
\text { years }[\approx \$ .87 \text { million per } \\
\text { year]. Uses: Station area } \\
\text { master plans and/or urban } \\
\text { center studies }{ }^{16}\end{array}$ \\
\hline
\end{tabular}

${ }^{6}$ Metro. 2009. State of the Centers Report.

${ }^{7}$ PSRC. 2008. Vision 2040.

${ }^{8}$ SANDAG. 2003. Smart growth definition, principles, and designations.

${ }^{9}$ DRCOG. 2005. Chapter 3: Elements of Metro Vision 2030 Plan. Metro Vision 2030 Plan.

${ }^{10}$ Metro. 2008. 2008-11 Metropolitan Transportation Improvement Program. January 2008, 12.

${ }^{11}$ PSRC. 2008. 2010-13 Transportation Improvement Program (TIP). Appendix C - Policies and Procedures.

${ }^{12}$ SANDAG. 2008. Final 2008 regional transportation improvement program.

${ }^{13}$ DROCOG. 2010. Policy on TIP preparation. Procedures for preparing the 2012-2017 TIP. Adopted July 21, 2010.

${ }^{14}$ Source: http://www.oregonmetro.gov/index.cfm/go/by.web/id=18459

${ }^{15}$ Source: http://www.sandag.org/index.asp?projectid=340\&fuseaction=projects.detail

${ }^{16}$ Source: http://www.drcog.org/index.cfm?page=StationAreaUrbanCenterPlanningFunds 
SANDAG

SANDAG's RCP presents a vision for the region, but it does not contain enforcement provisions. The definition of centers ranges in scale and intensity from metropolitan and urban centers to town and community centers. These areas are (or have the potential to become) areas with compact, higher-density, mixed-use, pedestrian-oriented activities (Barbour and Teitz 2006). To support development at these centers, SANDAG created the Smart Growth Incentive Program, which was launched as a $\$ 17$ million pilot in 2005 using federal transportation funding (SANDAG 2005). In 2009 SANDAG began administering a 40-year, $\$ 280$ million program funded through an allocation of 2 percent of the annual TransNet sales tax revenue (SANDAG 2010). The program offers grants to local governments for planning or capital projects at designated centers (SANDAG 2008b).

SANDAG first incorporated smart-growth criteria into its regional TIP in 1997 (CH2MHill 2005). The criteria have been updated several times, the last change coming in 2008 through an ad hoc working group. In each funding category, SANDAG has developed guidelines for how projects are scored. For example, highway corridor projects can receive up to nine points if they serve (1) existing/planned metropolitan or urban centers (five points), (2) existing/planned special-use centers (three points), and (3) potential urban or special-use centers (one point). A project receiving seven or more points receives the full 5 percent allocation in the regional TIP scoring process.

\section{DRCOG}

DRCOG's Metro Vision 2035 outlines the formation of urban centers, rural town centers, and freestanding communities for the purpose of decreasing urban sprawl and increasing infill. DRCOG does not have land-use authority, so transportation programs and TIP funding are important tools for influencing land-use decisions (DRCOG 2009). DRCOG also works collaboratively with local governments and the RTD to promote TOD. The development of TODs goes hand-in-hand with the implementation of FasTracks throughout the region, which is a taxpayer-funded RTD program to rapidly increase the amount of transit services (light rail and bus rapid transit) in the region. While FasTracks funds are allocated by RTD, they work closely with DRCOG (DRCOG no date).

There are currently three separate processes for selecting transportation projects to receive federal funds within the Denver region. DRCOG, the Colorado Department of Transportation (CDOT), and RTD each select projects over which they have authority, but DRCOG has final approval authority as the region's federally designated MPO (DRCOG 2006). The three agencies have undertaken four efforts to improve coordi- nation in project selection: (1) utilizing "strategic corridors" as the unifying theme, (2) participating in each other's meetings on project selection, (3) concurrence of DRCOG project selections with RTD and CDOT and (4) holding interagency reviews on draft TIP project lists. As noted in Table 3, DRCOG currently dedicates up to 13 percent of its criteria to projects that serve urban centers. This policy has evolved from a more qualitative process that awarded points for projects that served centers and increased population density (DRCOG 2006; DRCOG 2010).

\subsection{Summary}

In summary, the development of centers is an important objective in all four case-study regions, and the regional agencies have used a range of approaches to support those centers:

- All four regions have developed a regional plan with centers designated and classified.

- All four regions are using criteria in TIP funding to create incentives for projects that support centers.

- Three of the regions have grant programs to support local government planning and in some cases infrastructure.

\section{$3 \quad$ Findings}

In this section, we review the findings from our surveys, interviews, and forum regarding center policies, TIP criteria, and their effects on local planning and implementation.

\subsection{Policy findings of centers}

First, a majority of respondents in all four regions believed the centers' policy was influencing local jurisdictions (see Table 4). Many local governments in all four regions were using the regional centers policy as a basis for their comprehensive plan updates - even in Denver and San Diego, where the regional plans have no statutory authority. However, in both surveys and interviews, people believed the policies were more effective in reinforcing center policies in jurisdictions that were already implementing them rather than providing significant inducements for local governments to develop new policies.

Second, respondents indicated that the overall impact of the policy was limited because the scale of the need was so great relative to the levels of funding. Most designated centers have significant planning needs, such as specific area plans, circulation plans, and planning processes to address community concerns about higher densities. Many of these areas also have significant infrastructure needs, ranging from pedestrian improvements to streetscape, parking, and intersection improvements. Local governments are struggling to allocate resources to support centers, particularly with significant constraints on 
budgets.

A third issue relates to both the impact and scale of the policies. A majority of respondents did not believe that the centers' policy was "significantly influencing private investment" (see Table 4). People cited specific projects where successful development occurred, but noted that the scale of public investment is small relative to the need and relative to the private investment required. A state agency respondent in Puget Sound noted that local government plans lined up well with the growth center policy but that "the actual location decisions made by individuals and businesses reflect very different priorities."

A fourth issue emerging in all four regions was tension with the regional allocation of funding. On the one hand, there is a desire to provide the opportunity for all jurisdictions across the regions to develop centers. On the other hand, this means that limited funds are spread even more thinly. In interviews and surveys, respondents pointed to suburban and rural centers as raising the most debate because of their limited ability to be served by transit. For example, a local government representative in the Denver region commented, "In making the urban center concept available to all member governments, the concept has been diluted too much." Interviewees in several regions explained that funds were made available across the entire region to gain the political support necessary to have the money allocated.

\subsection{Analysis of TIP incentives}

Like the smart growth center policies, the use of TIP criteria to create incentives for growth centers generated mixed reviews in interviews and surveys. However, an important caveat is that these programs are all relatively new. As shown in Table 5, a majority of participants in each region believed that the TIP evaluation criteria had a significant effect on transportation decisions, which is not surprising given that the TIP is fundamentally a transportation-funding program. Their assessment of the impacts on land-use decisions was more mixed. Our research highlighted several themes from our cases.

First, in regions such as Portland and Puget Sound, a relatively small percentage of regional transportation funding is allocated by the MPO through the TIP process. For example, in metropolitan Portland, out of about $\$ 800$ million spent yearly in the whole region on transportation only about $\$ 33$ million, or 4 percent, per year is allocated by the MPO (City Club of Portland 2010). In Puget Sound, interviewees noted that the funding allocated using these criteria represents only about 10 percent of the total TIP funds (Regional Transportation Commission 2006). As a result, the criteria affect only a small percentage of the regional funding, with the rest allocated through the state and local processes and criteria. In contrast, regional funding in California is apportioned by state statute, with 75 percent of state transportation improving funds allocated to re- gions. As a result, SANDAG controls a majority of the region's transportation improvement investment.

Second, when we asked respondents to cite specific examples of how TIP criteria have affected land-use decisions, none could cite any. Respondents noted that TIP had no or very limited direct effect on land-use decisions. For example, a local government respondent in the San Diego region noted, "The regional TIP does not impact our decision-making process."

Third, it was clear from interviews and TIP-funding allocation data that the smart-growth components were a small proportion of the overall TIP criteria in some regions. As a result, scoring on the smart-growth criteria was not always a critical factor in obtaining funding. For example, we analyzed the scoring of projects in SANDAG's 2008 regional TIP (SANDAG 2008a) and found that none of the 10 freeway connector projects scored any points for serving regional and/or corridor transit routes (15 percent of criteria). Fifty-two highway connector projects were scored, and of the 19 that were funded, 11 scored zero or one for serving smart-growth areas (out of five), and only one funded project received all five points. In contrast, of the 13 transit projects that were funded (out of 43 proposed), 10 scored at least seven out of 15 points and the top five all scored between 8.5 and 15 points.

Finally, as with the growth centers funding, interviewees and survey respondents noted that adjustments to TIP funding criteria has raised tensions about the distribution of funding across the region. There is a tension between efforts to "spread the political peanut butter" and policies that tend to favor transportation improvements in urban centers. However, respondents in all four regions noted that the policy "could be better if a more significant investment were made in larger chunks."

\subsection{Cumulative effects}

Although centers' policies, grant programs, and TIP criteria did appear to have significant incentives individually, a common theme that arose from interviews, surveys, and our forum was the cumulative effect of these policies. City staff noted that they could more easily sell city investment to elected officials when there was grant funding available. Furthermore, when grants were flexible, they were helpful for augmenting projects with less flexible funding sources. For example, in San Diego local officials noted that TIP funding was an attractive additional incentive to develop around centers when supported by the smart-growth incentive grants, transit investment potential, and state affordable housing regulations. In Puget Sound and Portland, these incentive-based programs were an important compliment to regulatory growth management policies. For some local jurisdictions in Colorado and California, centers can also increase commercial development, which produces sales tax revenue for local governments. For all of these rea- 
Table 4: Evaluation of growth center incentive policy.

\begin{tabular}{|l|r|r|r|r|r|r|r|r|}
\hline \multirow{2}{*}{ Question } & \multicolumn{2}{|c|}{ Metro } & \multicolumn{2}{|c|}{ PSRC } & \multicolumn{2}{c|}{ SANDAG } & \multicolumn{2}{c|}{ DRCOG } \\
\cline { 2 - 8 } & Agree & Disagree & Agree & Disagree & Agree & Disagree & Agree & Disagree \\
\hline $\begin{array}{l}\text { [Centers' policy] supports what local jurisdictions } \\
\text { were doing already }\end{array}$ & $31 \%$ & $33 \%$ & $46 \%$ & $28 \%$ & $50 \%$ & $27 \%$ & $59 \%$ & $14 \%$ \\
\hline $\begin{array}{l}\text { [Centers' policy] has influenced local jurisdictions to } \\
\text { focus more development within centers }\end{array}$ & $74 \%$ & $9 \%$ & $74 \%$ & $6 \%$ & $84 \%$ & $4 \%$ & $61 \%$ & $14 \%$ \\
\hline $\begin{array}{l}\text { There are significant incentives for local jurisdictions } \\
\text { to promote growth within centers }\end{array}$ & $35 \%$ & $26 \%$ & $40 \%$ & $40 \%$ & $47 \%$ & $27 \%$ & $20 \%$ & $53 \%$ \\
\hline $\begin{array}{l}\text { The geographic distribution of centers has been } \\
\text { equitable }\end{array}$ & $17 \%$ & $37 \%$ & $52 \%$ & $24 \%$ & $69 \%$ & $15 \%$ & $24 \%$ & $26 \%$ \\
\hline $\begin{array}{l}\text { [Centers' policy] has significantly influenced private } \\
\text { investment }\end{array}$ & $17 \%$ & $26 \%$ & $26 \%$ & $28 \%$ & $27 \%$ & $19 \%$ & $12 \%$ & $37 \%$ \\
\hline
\end{tabular}

Table 5: Evaluation of TIP smart-growth criteria. Question: Please rate the significance of the TIP evaluation criteria on the following.

\begin{tabular}{|l|r|r|r|r|r|r|r|r|}
\hline & \multicolumn{2}{|c|}{ Metro } & \multicolumn{2}{c|}{ PSRC } & \multicolumn{2}{c|}{ SANDAG } & \multicolumn{2}{c|}{ DRCOG } \\
\hline & Significant & Insignificant & Significant & Insignificant & Significant & Insignificant & Significant & Insignificant \\
\hline $\begin{array}{l}\text { Effect on transpor- } \\
\text { tation decisions } \\
\text { across region }\end{array}$ & $79 \%$ & $7 \%$ & $81 \%$ & $2 \%$ & $79 \%$ & $14 \%$ & $88 \%$ & $5 \%$ \\
\hline $\begin{array}{l}\text { Effect on land-use } \\
\text { decisions across } \\
\text { region }\end{array}$ & $47 \%$ & $25 \%$ & $33 \%$ & $26 \%$ & $31 \%$ & $31 \%$ & $26 \%$ & $36 \%$ \\
\hline Sample size & & & & & & & & \\
\hline
\end{tabular}

sons, respondents and interviewees emphasized that grants and incentives needed to be part of a comprehensive regional plan with a cross section of supporting plans and policies.

\section{$4 \quad$ Implications}

As noted in the introduction, the goal of our study was to assess these regional center policies as they have been implemented thus far. Our secondary goal was to identify the ways in which the policies in these four regions could be improved, and we gathered information on this through surveys, interviews, and our forum. At our research forum we also discussed policy implications for the regional, state, and national levels.

\subsection{Improving regional center policies}

When survey respondents were asked to list three things that could improve the policies of their region's centers, those most commonly cited were technical assistance, funding, and policies that support transit and active transportation (biking and walking). Technical assistance was rated as the top item in three of four regions, and most of the responses could be classified into four categories:
- Technical planning assistance: guidance on improving zoning codes to support transit, walking, and biking; templates for how to "get the right parts and players" to support development at centers; options for better parking management; planning consultant expertise to identify specific needs at centers; codes to support transit, walking, and biking

- Technical development assistance: financing strategies for affordable housing; approaches to leveraging local dollars and helping businesses get assistance; options for phasing of improvements; guidelines for assessing development potential

- Best practices: highlights of successful projects; demonstration projects that can serve as models; good and bad lessons learned from other projects; templates or "how to" documents that guide cities on how to start work on centers

- Education and outreach information: images, case studies, demographic trends, and cost savings associated with developing centers

Second, local planners face a range of needs related to promoting development at centers. Some needs are due to a lack of staff time and capacity to undertake planning. Some of these needs originate from communities that have few mixeduse centers and lack experience with their development. Some of these needs are related to community resistance to higher density. In all four regions, local governments that adopted 
center policies encouraging higher-density development faced opposition from local residents who were concerned about the impacts on their neighborhood.

Third, survey respondents and interviewees cited the need for additional funding to invest in centers. Some of the funding needs were more investment to enhance centers, grants for local planning, and providing larger grants rather than trying to spread limited funding thinly across many jurisdictions. Respondents also emphasized the need to further support centers by leveraging other policies, such as economic development and tax incentives.

Fourth, survey respondents emphasized the need for regional policies that encourage transportation enhancements to support centers. Major investments in transit were clearly a strong trigger for land use changes and private investment. In some cities, the potential for future transit also helped encourage local government policy changes. Respondents also emphasized complimentary policies to support the functionality of these centers. This included prioritizing bus service for centers and more investment in bike and pedestrian infrastructure that would support centers.

Finally, some respondents identified a need for MPOs to better integrate performance measures that would reward local municipalities and regional agencies for supporting centers. For example, performance measures supporting reduction in vehicle miles traveled (VMT) could provide more support for centers but would likely favor more urban and transit-served centers.

\subsection{Policy implications}

One of the inherent implications of our study is that MPOs have the ability to develop regional plans to support centers and create financial incentives that will support their development. While these policies have long been associated with growth management states such as Oregon and Washington, the San Diego and Denver cases demonstrate that these policies can also be used by MPOs without land-use planning authority. Any MPO that oversees a regional transportation plan and allocates TIP funding can develop these policies, and smart-center grant programs are gaining momentum in several metropolitan regions. For example, the Atlanta Regional Commission Board has allocated $\$ 500$ million to support planning and projects as part of its Livable Centers Initiative (LCI). The initiative provides planning grants to local governments and nonprofit organizations for enhancing town centers, activity centers, and corridors as well as funds to help implement the plans (ARC 2010). Similarly, since our case study was completed, SANDAG reallocated $\$ 800$ million in cost savings from a freeway expansion project to non-highway projects such as rail grade separation, improving access to public transit centers, and the smart-growth incentive program. As a result,
SANDAG will add $\$ 300$ million to the $\$ 299$ million already allocated to the Smart Growth Incentive program (Hawkins 2011).

Another policy option raised at our forum was the linking of state and federal transportation funding to specific performance metrics that would support center investment. This could encourage more MPOs to focus on policies that support performance metrics. However, policy changes such as this present some significant challenges. Participants noted that many MPOs are small organizations without the staff or capacity, and this kind of direct funding would probably only be suitable for the largest MPOs. Furthermore, a policy rewarding center investment would confront the funding tensions that exist between many MPOs and state departments of transportation (DOTs). MPOs tend to be looking at a range of factors that define the livability of a region, while many DOTs are looking at the issues more narrowly, such as statewide movement of goods and people. Not only does this produce tensions about where transportation funds should be allocated, but this policy change would also likely entail shifts in funding from state transportation agencies to MPOs.

Finally, in all of the regions, the importance of transit investment and coordination between MPOs and transit agencies was critical. In Denver and San Diego, the additional sales tax revenue for expansion of transit has been a key incentive for local governments to develop centers within their jurisdiction. One of the significant issues that arose in all four regions is the governance arrangements that facilitate and constrain MPOs to effectively coordinate with regional transit agencies. In San Diego, SANDAG has the authority for regional transit planning, while the transit agencies operate the systems. Both Metro and DRCOG have a close working relationship with their transit agencies, developing joint plans and linking regional land-use policies with potential future transit corridors. Puget Sound has six transit agencies: five provide local service at the county or city level and Sound Transit provides high-capacity regional service in the urbanized portions of three counties. While there is extensive coordination between agencies at the regional level, survey respondents and forum participants believed that the number of agencies involved made coordination more complex. Metropolitan governance is beyond the scope of this paper, but it is clearly an important factor affecting regional land and transportation decision making.

\section{Conclusion}

The growth center policies being trialed in the four metropolitan regions are early in their development. It is clear from our study that none of the individual policies is a panacea for promoting development of metropolitan centers. However, we found that when several policies are combined to reinforce investment in centers, they can have an important cumulative 
effect. Based on the rate at which local governments in the four regions are developing centers, it is also clear that it will take many years of concerted effort to influence the form of metropolitan development and assess the impact of these policies in terms of land use and transportation outcomes.

Our study findings contribute to the literature on smart growth and transit-oriented development by highlighting the role that MPOs can play on a regional scale. This role is stronger in regions where regional agencies have land-use authority, but in all of our case-study regions, incentive-based programs and transit investment were important influences. This suggests that MPOs and regional agencies throughout the country can influence the pattern of urban development through incentive-based policies. The policies have faced political challenges and debates of equitable distribution of funding, but the level of investment now being undertaken in regions such as San Diego and Atlanta indicates these policies can gain momentum over time.

As metropolitan regions continue to face challenges of air quality, congestion, housing affordability, and reduced federal funding, it will be increasingly important for MPOs and regional agencies to develop metropolitan plans and policies. During our forum, participants noted that federal transportation legislation offers an opportunity to reinforce this approach, particularly if funding is more closely linked with a broader array of performance measures and focused on livability objectives.

\section{Acknowledgments}

The authors would like to thank the reviewers for their helpful comments on the draft and staff from the metropolitan planning organizations who participated in this project. The authors would also like to acknowledge the contributions of the Community Planning Workshop graduate student team that worked on this project: Project manager Jeremy Sande, Claire Otwell, Christina Bond, Mark McCaffery, and Adam Erickson. This project was made possible with funding from the Oregon Transportation Research and Education Consortium (OTREC), the Oregon Department of Transportation, and the Federal Highway Administration STEP Research Program.

\section{References}

ARC. 2010. Livable Centers Initiative 2010. http://www.atlantaregional.com/File\%20Library/Land\%20Use/LCI/ lu_lci_brochure_3rd_2010.pdf.

Barbour, E. and M. B. Teitz. 2009. Blueprint planning in California: An experiment in regional planning for sustainable development. In Toward sustainable communities: Transition and transformations in environmental policy, edited by D.A. Mazmanian and M.E. Kraft, 171-200. Cambridge, MA: MIT Press.

Barbour, E. and M. B. Teitz. 2006. Blueprint planning in California: Forging consensus on metropolitan growth and development, 171-200. San Francisco, CA: Public Policy Institute of California. http://www.ppic.org/content/pubs/op/ OP_606EBOP.pdf.

Bernick, M. and R. Cervero. 1997. Transit villages in the 21st century. New York: McGraw-Hill.

Calthorpe, P. 1993. The next American metropolis: Ecology, community and the American dream. New York: Princeton Architectural Press.

Cervero, R. 2003. Growing smart by linking transportation and land use: Perspectives from California. Built Environment, 29(1): 66-78. doi:10.2148/benv.29.1.66.53948

Cervero, R., C. Ferrell, and S. Murphy. 2002. Transit-oriented development and joint development in the United States: A literature review. TCRP Research Results Digest 52.

$\mathrm{CH} 2 \mathrm{MHill}$. 2005. Integration of quality growth policies into transportation planning. Portland, OR: Atlanta Chamber of Commerce.

City Club of Portland. 2010. Moving forward: A better way to govern regional transportation. City Club of Portland Bulletin 96(32): 1-67. http://pdxcityclub.org/sites/default/files/ reports/Transportation_Governance_2010_0.pdf.

Dittmar, H. and G. Ohland. 2004. The new transit town: Best practices in transit-oriented development. Washington, DC: Island Press.

DRCOG. 2011. Metro Vision 2035 Plan. Denver, CO: Denver Regional Council of Governments.

DRCOG. 2000. Mile High Compact. Denver, CO: Denver Regional Council of Governments.

DRCOG. 2010. Policy on transportation improvement program (TIP) preparation: Procedures for preparing the 2012-2017 TIP. Denver, CO: Denver Regional Council of Governments.

DRCOG. 2006. Policy on transportation improvement program preparation. Denver, CO: Denver Regional Council of Governments. http://www.drcog.org/documents/2007201 2TIPPolicyAmendedFinal0106.pdf. 
DRCOG. 2009. Transportation planning in the Denver region. Denver, CO: Denver Regional Council of Governments.

DRCOG. 2009. With one voice. Denver, CO: Denver Regional Council of Governments. http://www.drcog.org/ documents/2009\%20With\%20One\%20Voice\%20Brochure\%204\%20web.pdf.

Dunphy, R. T. 2004. Developing around transit: Strategies and solutions that work. Washington, DC: Urban Land Institute.

Handy, S. Correlation or causality between the built environment and travel behavior? Evidence from Northern California. Transportation Research: Part D 10, 6(2005):42744. doi:10.1016/j.trd.2005.05.002.

Hawkins, R. J. 2011. SANDAG moves $\$ 800 \mathrm{M}$ from I-5 into transit-oriented projects. San Diego Union-Tribune, July 22, 2011.

Hendricks, S. J. and K. Seggerman. 2005. Incorporating transportation demand management into the land development process. Tampa, FL: Center for Urban Transportation Research, University of South Florida. http://www.nctr.usf. edu/pdf/576-11.pdf.

Ingram, G. K., ed. 2009. Smart growth policies: An evaluation of programs and outcomes. Cambridge, MA: Lincoln Institute of Land Policy.

Metro. 2008. Metropolitan transportation improvement program. Portland, OR: Metro Council.

Metro. 2010. Metropolitan transportation improvement program. Adoption Draft. September 2010. Portland, OR: Metro Council.

Metro. Urban growth management functional plan. Portland, OR: Metro Council, 2007.

Miller, J. S., R. W. Howe, R. P. Hartman, and A. K. Goswami. 2004. Options for improving the coordination of transportation and land-use planning in Virginia. Charlottesville, VA: Virginia Transportation Research Council. http://www.virginiadot.org/vtrc/main/online\%5Freports/pdf/04-r14.pdf.

Nelson, D., and J. S. Niles. 1999. Market dynamics and nonwork travel patterns; obstacles to transit-oriented development? Transportation Research Record 1699, 2:13-21. doi:10.3141/1669-02.

PSRC. 2009. 2010-2013 transportation improvement program. Seattle, WA: Puget Sound Regional Commission. http://www.psrc.org/transportation/tip/current/1013tip/.

PRSC. 2008. Chapter 7: Discussion of discussion of multicounty planning policies. Vision 2040 final environmental impact statement. Seattle, WA: Puget Sound Regional Commission.

PRSC. 2009. The Washington State Growth Management Act with Applications for the Central Puget Sound Region. Seattle,
WA: Growth Management Department, Puget Sound Regional Council.

PRSC. 2010. Transportation 2040: Toward a sustainable transportation system. Seattle, WA: Puget Sound Regional Commission.

Reconnecting America. 2011. 2010 Inventory of TOD programs: A national review of state, regional and local programs that fund transit-oriented development plans and projects. Washington, DC: Reconnecting America.

Regional Transportation Commission. 2006. Final Report. Olympia, WA: Regional Transportation Commission.

Rodíguez, D.A. and D.R. Godschalk. 2003. The connection between land use and transportation in land-use plans. Raleigh, NC: North Carolina Department of Transportation.

SANDAG. n.d. About SANDAG: History. San Diego Association of Governments. http://www.sandag.org/index. asp? fuseaction=about.history.

SANDAG. 2011. Demographics and other data: Fast facts. San Diego Association of Governments. http://www.sandag.org/resources/demographics_and_other_data/demographics/fastfacts/regi.htm.

SANDAG. 2008a. Final 2008 regional transportation improvement program. San Diego, CA: San Diego Association of Governments.

SANDAG. 2004. Regional comprehensive plan for the San Diego region. San Diego, CA: San Diego Association of Governments.

SANDAG. 2001. Regional housing needs assessment (RHNA). San Diego, CA: San Diego Association of Governments.

SANDAG. 2008b. Smart growth incentive program: Guidelines and call for projects. FY 2009-FY 2010. Capital grants. San Diego, CA: San Diego Association of Governments.

SANDAG. 2005. Transnet smart growth incentive program factsheet. San Diego, CA: San Diego Association of Governments.

U.S. Census Bureau. n.d. Metropolitan and Micropolitan Data: 2010 Decennial Census.

Zimbabwe, S. and A. Anderson. 2011. Planning for TOD at the regional scale: The big picture. Washington, DC: Federal Transit Administration. http://ctod.org/pdfs/tod204.pdf. 